\title{
Screening for antibodies against the sheep scab mite (Psoroptes ovis) \\ Pso o 2 antigen in experimentally infested Swifter sheep may fail to identify affected animals
}

\author{
Screening van antilichamen tegen het Pso o 2-antigeen van de \\ schurftmijt (Psoroptes ovis) bij experimenteel geïnfecteerde swifterschapen \\ kan de aangetaste dieren mogelijk niet identificeren
}

\author{
${ }^{1}$ R. Meyermans, ${ }^{2}$ K. Bartley, ${ }^{1}$ S. Janssens, ${ }^{2}$ S.T.G. Burgess, ${ }^{1}$ N. Buys
}

${ }^{1}$ Department of Biosystems, KU Leuven, 3001 Leuven, Belgium

${ }^{2}$ Moredun Research Institute, Pentlands Science Park, Bush Loan, Edinburgh, Midlothian, EH26 0PZ, UK

nadine.buys@kuleuven.be

\begin{abstract}
$\Lambda$
BSTRACT

Sheep scab, caused by Psoroptes ovis mites, represents a significant threat to sheep health and welfare. Infestations are diagnosed by parasite identification in skin scrapings, and more recently with a commercial ELISA against serum antibodies to the Pso o 2 mite allergen. However, little is known about the performance of the ELISA in non-UK sheep populations. In this study, six Swifter sheep were experimentally infested with $P$. ovis. Lesion sizes were monitored and serum IgG against Pso o 2 and the novel Pso-EIP-1 antigens were measured by ELISA. Although all sheep showed signs of infestation, serum from two animals failed to react with Pso o 2. However, they did react to Pso-EIP-1. This indicates that cases of sheep scab in (Swifter) sheep may remain undetected using the Pso o 2 ELISA, which may have implications for routine screening of nonUK sheep breeds.
\end{abstract}

\section{SAMENVATTING}

Schapenschurft, veroorzaakt door Psoroptes ovis-mijten, heeft een grote impact op de gezondheid en het welzijn van schapen. Besmettingen worden vaak gediagnosticeerd door identificatie van de parasieten in huidafkrabsels en recentelijk is een commericiële ELISA tegen het Pso o 2-allergeen beschikbaar. Er is echter weinig bekend over de bruikbaarheid van deze ELISA bij niet-Britse schapenpopulaties. Zes swifterschapen werden experimenteel besmet met $P$. ovis. De grootte van de laesies werd opgevolgd en vergeleken met de serum-IgG tegen Pso o 2 en het nieuwe Pso-EIP-1-antigeen via ELISA. Hoewel alle schapen huidletsels vertoonden, konden bij twee dieren geen serum-IgG tegen Pso o 2-allergenen aangetoond worden, in tegenstelling tot serum-IgG tegen Pso-EIP-1. Dit geeft aan dat gevallen van schapenschurft bij (swifter)schapen mogelijk onopgemerkt blijven tijdens de diagnose met behulp van de Pso o 2-ELISA, wat gevolgen kan hebben bij een routinematige screening van nietBritse schapenrassen.

\section{INTRODUCTION}

The mite Psoroptes ovis causes sheep scab, also termed psoroptic mange, a disease that is considered to be the most important ectoparasitic disease in sheep in the UK, from both welfare and economic perspectives (Nieuwhof and Bishop, 2005). Infestation with
P. ovis mites causes severe skin irritation and pruritus, causing serious animal welfare concerns. In a recent study, it has been shown that the cost of sheep scab to the UK sheep industry could be as high as £78200 million per annum (Nixon et al., 2020). These costs include performance loss, costs of preventive measurements and treatment of affected animals. The 
disease is highly contagious and can be difficult to control, especially with the recent emergence of $P$. ovis mite populations resistant to the macrocyclic lactone injectables, which are heavily relied upon for its control (Doherty et al., 2018; Sturgess-Osborne et al., 2019). Therefore, routine screening of flocks can be a valuable tool in the control of sheep scab; especially because an overreliance on the appearance of clinical signs can fail to detect subclinical carriers of $P$. ovis. To counter this, Nunn et al. (2011) developed a serological test capable of detecting sheep scab within two weeks of an infestation and prior to the appearance of clinical signs (Nunn et al., 2011). The test is highly sensitive (98.2\%) and specific (96.5\%) (Hamer et al., 2019) and can effectively diagnose the disease in a natural outbreak, even in subclinically infested animals (Burgess et al., 2012). The ELISA relies upon the detection of host antibodies against the $P$. ovis antigen, Pso o 2 protein. The test has been widely applied in the UK; however, little is known about its performance in other, non-UK sheep breeds and populations. The aim of this research was to validate the use of the Pso o 2 antigen test in Swifter sheep, a non-UK sheep breed common in Belgium and the Netherlands.

\section{METHODS}

In the current experiment, six Swifter sheep, a breed that originates from a cross between Texel and Flemish sheep, were infested with live $P$. ovis mites. For a period of eleven weeks prior to infestation, all sheep were monitored by visual inspection to ensure that they were free of infestation and they were screened using the psoroptic mange Pso o 2 ELISA (starting 2.5 months before infestation). All sheep remained free of infestation prior to the start of the study and their serological responses (anti-Pso o 2) were also negative $\left(\mathrm{OD}_{450 \mathrm{~nm}}<0.2\right)$. For the infestation, live $P$. ovis mites (mixed life cycle stages) were collected from experimentally infested sheep at the Moredun Research Institute (MRI). Approximately 50 to 100 live mites were placed at the withers, directly on the skin of the animals. The fleece length was approximately $50 \mathrm{~mm}$ in all six sheep. The sheep were housed together in the same pen for the duration of the study at the experimental facilities of KU Leuven. The developing lesion dimensions were measured on a weekly basis for five weeks post infestation (wpi). This was done by restraining the animal on a cradle and determining the size of the lesion, while ensuring that the developing lesions were not disturbed. Serum was collected weekly (up to six wpi) from the jugular vein and serological responses (IgG) against the Pso o 2 antigen were measured using the MRI sheep scab ELISA as previously described (Nunn et al., 2011). As a follow-up, the serum samples were also analyzed for $\operatorname{IgG}$ responses against the novel Pso-EIP-1 antigen with a highly sensitive and specific
ELISA as described by Burgess et al., 2020. ELISA cut-off values were calculated as mean absorbance of the negative controls plus three times the standard deviation of the negative controls. To estimate correlations, the Pearson correlations coefficients were calculated (cor() and cor.test() function in R) (Kutner et al., 2005). At the end of the experiment (five wpi), all sheep were treated with ivermectin subcutaneously (Ivomec F, Boehringer Ingelheim, Belgium; 0.2mg/ $\mathrm{kg}$ body weight) and with a phoxim pour on solution (Sarnacuran 7.5\%, Bayer, 0.5g/l; Belgium).

\section{RESULTS}

Lesion development (lesion area in $\mathrm{cm}^{2}$ ) is shown in Figure 1A. There was a large degree of variation in lesion development between the individual animals, and two sheep (Animal 4 and 5) developed considerably larger lesions than the other animals. In figure $1 \mathrm{~B}$, the serological responses are shown for the six infested sheep from the sheep scab ELISA test (Pso o 2 antigen). One animal (Animal 4), which had the largest skin lesion at five wpi $\left(345 \mathrm{~cm}^{2}\right)$, failed to respond to the Pso o 2 antigen ELISA, whilst a further animal, with a medium sized lesion (Animal 6, 105 $\mathrm{cm}^{2}$ at four wpi) also appeared unresponsive. However, the other infested animals, with small to medium sized lesions did respond to the Pso o 2 antigen. The animals that were unresponsive to the Pso o 2 antigen, successfully responded to the Pso-EIP-1 antigen (Figure 1C); only Animal 3 failed to respond to the Pso-EIP-1 ELISA. Over the five weeks of infestation and considering all six animals, the general pearson correlation between the lesion size and Pso EIP-1 was 0.69 . Between the lesion size and Pso o 2, this correlation was 0.22. However, for some animals (Animal 3 and 6), Pso o $2 \mathrm{IgG}$ correlated better with the lesion size than Pso-EIP-1 IgG serum responses (Table 1).

\section{DISCUSSION}

Although the sample size of this cohort study was relatively small, the results show that under experimental conditions, some (Swifter) sheep appeared to be unresponsive to the Pso o 2 antigen. To the authors' knowledge, this is the first time that this serodiagnostic test has been applied in an experimental infestation with this breed.

In this small set of Swifter sheep, the test failed to detect two sheep with clinical sheep scab lesions. Moreover, the test failed to detect anti-Pso o 2 IgG in the animal with the largest lesion even at six wpi. A possible explanation could be that the animal with the largest (excessive) lesions has a lower antibody response; however, this does not explain why the animal only failed to react on one single tested antigen. General correlations between the lesion size and Pso o 2 
A

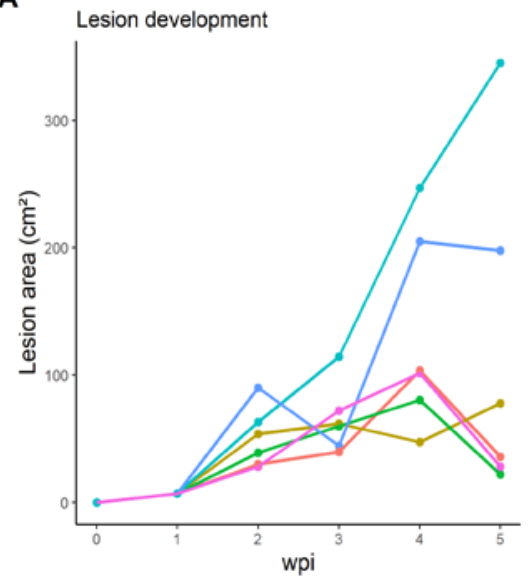

B

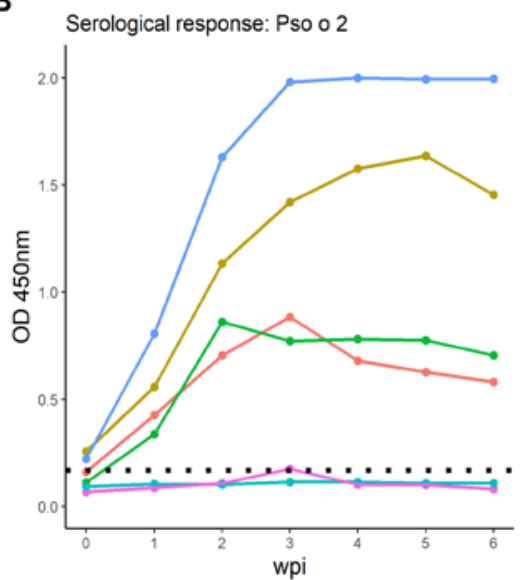

C

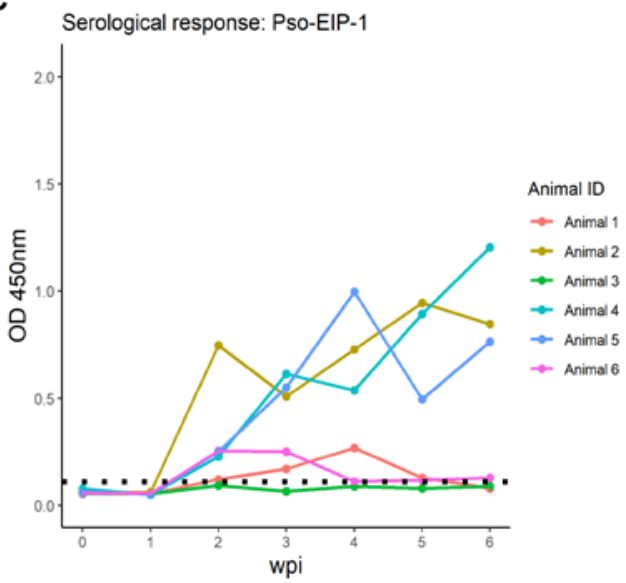

Figure 1. A. Lesion development of the six sheep for five weeks post infestation (wpi). B. Serological response of Pso o 2 expressed as optical density at $450 \mathrm{~nm}(\mathrm{OD} 450 \mathrm{~nm})$ for the six sheep up to six wpi, cut-off value at 0.17 (black dotted line). C. Serological response of Pso-EIP-1 expressed as optical density at $450 \mathrm{~nm}(\mathrm{OD} 450 \mathrm{~nm})$ for the six sheep up to six wpi, cut-off value at 0.11 (black dotted line).

IgG were low and were considerably higher between the lesion size and Pso-EIP-1 IgG, across all animals. However, in some individual animals, the lesion size correlated better with Pso o 2 IgG than with PsoEIP-1 IgG (e.g. for Animals 3 and 6), indicating that for some individuals, Pso o 2 IgGs follow the lesion development.

Animals 4 and 5 remained seronegative throughout the study with the Pso o 2 antigen, which the authors confirmed by repeat testing the ELISA to exclude false negative results. Therefore, it is unlikely that a technical issue was responsible for the false negative results in these two animals. However, there was no clear cause for the unresponsiveness in these sheep in this study. It is possible that the observed difference in responsiveness originated from a difference in immune response to $P$. ovis infestations from these unresponsive sheep in the Swifter population. As the mites that were used for the infestation originated from the UK and were harvested from UK-raised sheep, it could be argued that these mites were well adapted to the conditions and hosts in the UK. Nonetheless, the authors don't consider this as the main cause of the unresponsiveness to the Pso o 2 ELISA as all sheep developed clear signs of sheep scab. A false negative

Table 1. Individual (Pearson) correlation per animal between lesion size and the observed serological response (expressed as OD 450) for both $P$. ovis antigens (Pso o 2 and Pso-EIP-1).

\begin{tabular}{lcc}
\hline Sheep ID & Pso o 2 & Pso-EIP-1 \\
\hline Animal 1 & 0.575 & 0.979 \\
Animal 2 & 0.935 & 0.932 \\
Animal 3 & 0.747 & 0.652 \\
Animal 4 & 0.583 & 0.922 \\
Animal 5 & 0.760 & 0.798 \\
Animal 6 & 0.577 & 0.386 \\
\hline
\end{tabular}

rate of two out of six animals ( $\sim 33 \%$ false negative) is higher than the $3.5 \%$ false negative rate typical of traditional UK sheep breeds (Nunn et al., 2011). However, given the small number of Swifter sheep tested in the present study, it is feasible that the false negative rate has been inflated due to the small sample size. A follow-up experiment assessing a larger cohort of experimentally or naturally infested sheep to determine the proportion of Swifter sheep unresponsive to the Pso o 2 ELISA would inform about the false negative rate in Swifter sheep. Moreover, extending this research to other non-UK sheep breeds would be very useful to check whether the Swifter breed is the only breed displaying this rate of unresponsiveness to the Pso o 2 ELISA.

The Pso o 2 ELISA is a viable tool to $\operatorname{detect} P$. ovis infestations before clinical or behavioral signs become apparent, allowing farmers to start earlier with acaricide treatment (Burgess et al., 2012). In addition, the ELISA could be used to enhance biosecurity on-farm by screening quarantined sheep; it could be informative in health surveillance, accreditation and eradication programs (Hamer et al., 2019). However, this test should not replace any clinical assessment of the animals. Moreover, a combined antigen (Pso o 2 and Pso-EIP-1) ELISA could be a viable option in populations where unresponsiveness to the Pso o 2 ELISA has been shown.

\section{CONCLUSION}

In this cohort study, it is shown that confirmed cases of sheep scab in Swifter sheep may remain undetected using the Pso o 2 ELISA. This needs to be taken into account when determining the number of sheep to be tested in the screening of natural outbreaks of sheep scab, especially when testing populations, in which this test has not yet been verified, as is the case for 
most non-UK sheep populations. Moreover, it cannot be excluded that flocks may harbor one or more of these Pso o 2 unresponsive individuals. Therefore, the presence of unresponsive individuals must be taken into account when routinely screening sheep flocks for anti-Pso o $2 \mathrm{IgG}$. In many ways, this is countered by the use of the test flock, rather than testing on individual level. It is recommened to test at least twelve animals from each management group (Hamer et al., 2019). However, a further solution could be to develop a combined antigen test that screens serum for both Pso o 2 and Pso-EIP-1 IgG.

\section{ACKNOWLEDGEMENTS}

This research was approved by the ethical committee for the experimental use of animals of the KU Leuven under accession number P033/2019. This research was funded by a SB PhD fellowship (1S37119N) of the Research Foundation Flanders (FWO). The authors would like to thank the KU Leuven Transfarm staff for their support during the experiment.

\section{REFERENCES}

Burgess, S. T. G., Nunn, F., Bartley, K., Frew, D., McLean, K., Inglis, N. F., McGeachy, K., Taliansky, M. E., Love, A. J., Nisbet, A. J. (2020). Psoroptes ovis -Early Immunoreactive Protein (Pso- EIP- 1) a novel diagnostic antigen for sheep scab. Parasite Immunology 42, e12788. https://doi.org/10.1111/pim.12788

Burgess, S. T., Innocent, G., Nunn, F., Frew, D., Kenyon, F., Nisbet, A. J., Huntley, J. F. (2012). The use of a Psoroptes ovis serodiagnostic test for the analysis of a natural outbreak of sheep scab. Parasites \& Vectors 5, 7. https:// doi.org/10.1186/1756-3305-5-7
Doherty, E., Burgess, S., Mitchell, S., Wall, R. (2018). First evidence of resistance to macrocyclic lactones in Psoroptes ovis sheep scab mites in the UK. Veterinary Record182, 106. https://doi.org/10.1136/vr.104657

Hamer, K., Burgess, S., Busin, V., Sargison, N. D. (2019). Performance of the Psoroptes ovis antibody enzymelinked immunosorbent assay in the face of low-level mite infestation. Veterinary Record 185, 107. https://doi. org/10.1136/vr.105304

Kutner, M. H., Nachtsheim, C. J., Neter, J., Li, W. (2005). Inferences in regression and correlation analysis. In: R. Hercher (editor). Applied Linear Statistical Models. Fifth edition, McGraw-Hill - Irwin, 76-78.

Nieuwhof, G. J., Bishop, S. C. (2005). Costs of the major endemic diseases of sheep in Great Britain and the potential benefits of reduction in disease impact. Animal Science, 81, 23-29. https://doi.org/10.1079/ASC41010023

Nixon, E. J., Wall, R., Vineer, H. R., Stubbings, L. (2020). The high cost of sheep scab. Veterinary Record 187, 325325. https://doi.org/10.1136/vr.m3888

Nunn, F. G., Burgess, S. T. G., Innocent, G., Nisbet, A. J., Bates, P., Huntley, J. F. (2011). Development of a serodiagnostic test for sheep scab using recombinant protein Pso o 2. Molecular and Cellular Probes 25, 212-218. https://doi.org/10.1016/j.mcp.2011.09.002

Sturgess-Osborne, C., Burgess, S., Mitchell, S., Wall, R. (2019). Multiple resistance to macrocyclic lactones in the sheep scab mite Psoroptes ovis. Veterinary Parasitology 272, 79-82. https://doi.org/10.1016/j.vetpar.2019.07.007

Tg Burgess, S., Innocent, G., Nunn, F., Frew, D., Kenyon, F., Nisbet, A. J., Huntley, J. F. (2012). The use of a Psoroptes ovis serodiagnostic test for the analysis of a natural outbreak of sheep scab. https://doi.org/10.1186/17563305-5-7

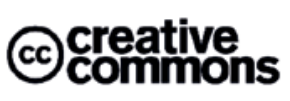

(C) 2021 by the authors. Licensee Vlaams Diergeneeskundig Tijdschrift, Ghent University, Belgium. This article is an open access article distributed under the terms and conditions of the Creative Commons Attribution (CC BY) license (http://creativecommons.org/licenses/by/4.0/). 